\title{
Critical Literacy: Conflicts, Challenges, Adaptations and
}

\section{Transformation?}

\author{
Nizar Kamal Ibrahim ${ }^{1 *}$ \\ ${ }^{1}$ Lebanese University, Faculty of Education, Beirut, Lebanon \\ * Nizar Kamal Ibrahim, E-mail: pronizar.ki@gmail.com
}

\begin{abstract}
This case study explored how the involvement of two ESL instructors in critical literacy research, including master's thesis, made them experience different challenges, ideological conflicts and successes. One of them was teaching ESL in secondary classes when she carried out her thesis about critical literacy. She also cooperated with the researcher in a critical literacy study after she had finished data collection for her thesis. The other participant taught ESL in elementary classes and is currently teaching at universities. The study, which took place in Lebanon, revealed how the varied ideological positions, views and contexts of the two instructors made them go through different transformations. The data suggests that involving teachers and masters'students in critical literacy research constitutes and important platform to train them in the various complex dimensions of critical literacy, particularly in settings where this approach faces significant resistance.
\end{abstract}

\section{Keywords}

critical literacy and professional development, critical literacy: challenges and transformations of novice and experienced teachers, ideological conflicts in ESL critical literacy classes

\section{Introduction}

Critical literacy, with its several directions, positions teachers as intellectuals who aim to promote equity and justice. However, teachers cannot develop this sociopolitical and socioeconomic vision of literacy education without a drastic change in the pre-service and in-service teacher-training programs as well as in second language education policies, curricula and institutional practices. Such changes are far from being realized in many parts of the world. It is, thus, left to initiatives taken up by individual educators here and there who challenge the status quo in their local contexts (Hall, 2005). Those educators face various challenges, including the changing nature of literacy, the technocratic view of literacy, the accountability placed on teachers by official exams (Morrell, 2005) and the complexity of critical literacy theories. This case study explored the challenges two ESL teachers faced in developing a successful critical orientation to literacy instruction and the transformations that resulted in their feeling that they are "very, very proud about it", as one of them said. The following questions guided the study: 
(1) How have the desires, the learning experiences, the ideologies and the contexts of the two instructors affected their critical literacy orientations?

(2) What challenges, conflicts and transformations have the two instructors experienced during their implementation of critical literacy instruction?

\section{The Theoretical Position}

Despite the particularities of various critical literacy orientations, including the Freirian approach, feminist and poststructuralist approaches, and text analytic approaches (Pennycook, 2001; Shor, 2009), they all view literacy (or literacies) as social practices related to broader social, ideological and political concerns (Cho, 2015; Freire, 2001; Morgan, 1997). From this perspective, literacy is constituted of the assumptions, beliefs, values, expectations, and related conceptual materials that occur in particular socio-historical circumstances (Gregory \& Cahill, 2009). Teachers wishing to adopt a critical literacy approach should develop a sound vision of these constituents that qualify any literacy act. This is compounded by the need to distinguish between critical thinking and critical literacy and to handle institutional and practical constraints to this orientation. To exemplify this complex task, the challenges that teachers may experience when adopting the Freirian approach will be discussed.

\subsection{Critical Thinking and Critical Literacy}

Teachers' whose enthusiasm for critical work refers to their misunderstanding of critical literacy as developing the students' critical thinking skills should distinguish between the two. Critical thinking encompasses the skills of problem-solving, of evaluating the credibility of any argument, and of making intelligent and informed choices. It aims to bring "more rigorous analysis to problem solving or textual understanding (and to develop) more critical distance as it is sometimes called. (In a critical thinking class, teachers) assume an objectivist view of knowledge and instruct students to evaluate texts' 'credibility', 'purpose', and 'bias', as if these were transcendent dualities" (Pennycook, 1999, p. 51). Advocates of critical thinking espouse an apolitical version of critical language research and pedagogy (Benesch, 1993), which is a far cry from the sociopolitical and socioeconomic work of critical applied linguistics, to which "a central issue always concerns how the classroom, text, or conversation is related to broader social, cultural and political relations" (Pennycook, 1999, p. 51). Thus, teachers interested in critical work should be able to understand these relationships and to adopt a clear ideology compatible with the vision of critical applied linguistics, to which an apolitical view of critical thinking is irrelevant. However, this does not mean that teaching students critical thinking strategies is not important. As Morgan (1997) emphasizes, we need to develop these skills to understand the technicalities of crafting texts in order to explore their sociopolitical and socioeconomic effects. Hence, teachers should possess the ability of integrating critical thinking and critical literacy, based on a clear vision of the role of literacy education in promoting equity and justice. 


\subsection{The Freirian Approach}

Freire $(1993,2001)$ theorizes that in order to help people recognize the conditions that inhibit the realization of their full humanity, pedagogues should adopt problem-posing education, which engages students in questioning situations, knowledge and texts through the lens of equity and justice (Freire \& Macedo, 1987; Giroux, 2007). Through problem-posing education, teachers can arouse students' epistemological curiosity, which develops when one is increasingly critical in his learning (Freire, 1993, 2001). This implies being systematically critical in approaching the various tasks of the human being, including education. Epistemological curiosity should seek to interrogate the relationship between knowledge and the pedagogic context that produces it, as well as the connection between education on one hand and the socioeconomic, sociopolitical and the ideological trends that circumscribe it at a particular time, on the other hand (Bercaw \& Stooksberry, 2004; Freire, 2001). This situatedness of learners, educators and knowledge (Connolly, 2013) demands that teachers relate the individual learning experiences to the political, social and cultural concerns of the local communities and of the world (Freire, 2001; Gregory \& Cahill, 2009). The implication of this philosophy to literacy education is that critical reading means ownership of the meaning-making process and a creative challenge of the text's authority, in which the reader is not "just a captive of the mind of the text as if it were simply a product of its author" (Freire, 2001, p. 34). From this point of view, as students read words, they analyze their implications to their lives and to how the world is constructed, and they come to recognize different forms of struggle and collective action (Shor, 2009).

\subsubsection{Praxis and Ideological Clarity}

In order to realize the Freirian vision of literacy education, teachers should be able to question their own discourses as well as the discourses of their communities. But can they do that easily, particularly that critiquing the ideologies dominant in one's social milieus means a critique of one's identity, which is socially constructed? Some educators raise some doubts about this (e.g., Bercaw \& Stooksberry, 2004; Bartolomé, 2004). For instance, Bartolomé (2004) argues that prospective and experienced educators alike resist challenging their own dominant ideologies which perpetuate inequality. She stresses that these teachers lack a political and ideological clarity that often translates into accepting the status quo as "natural". However, other scholars are more optimistic about the role of educators (e.g., Freire, 2001; Giroux, 2007; Shor, 2009). From this perspective, teachers have the potential to be transformative intellectuals who empowers students to be thoughtful (Giroux, 2007). This requires, among other things, that teachers become involved in praxis: Connecting theory and practice (Freire, 1993, 2001).

Connolly (2013) describes praxis as practice enriched by theory; it refers to "....informed activism, committed to human well-being, underpinned by critical reflection, honed by rigorous interrogation of our values and beliefs" (Smith, 1999; as cited in Connolly, 2013, p. 6). Praxis comprises the students' and the teachers' critical reflection on their assumptions and actions as well as on the world so that they develop critical consciousness of their situations and play their agentive roles in transforming 
oppressive conditions into more favorable ones; this requires that teachers avoid adhering just to theory, i.e., mere verbalism or immersing themselves in practice without clear theoretical grounds, i.e., mere activism (Freire, 2001). They should rather systematically reflect on action from a theoretical position as well as on theory from an activist position.

\subsubsection{Challenges}

Any critical pedagogue should imagine possible alternatives to the status quo and build his/her pedagogy around such possibilities, which according to Crookes (2010), helps us reconstitute the world. Thus, a dialectical process of reflection on the relationship between action and theory as well as on the relationship between education and the life conditions prevailing in the world helps teachers conceptualize transformative possibilities, based on an imagined better state of affairs. But do teachers caught in the various institutional and life demands have the luxury for such reflection? And if they do, how do they deal with the societal and institutional resistance to critical educational practices? As McLaughlin and DeVoogd (2004) explain, we cannot just become critical. We rather develop as critical beings over time, through a cyclical process of learning, acting critically, and reflecting. Through this process, we develop theoretical, research, and pedagogical repertoires that make critical literacy a natural part of our teaching. This, however, involves conflicts and resistance.

\subsection{Studies}

A number of publications examined the training both teacher students and in-service teachers receive in critical literacy, their views of this orientation, and the challenges they face during its class implementation. The publications explored innovative ways of involving both pre-service and in-service teachers in various dimensions of the praxis process (e.g., Cho, 2015; Crookes \& Lehner, 1998; Norton \& Toohey, 2004; Pavlenko, 2003; Pennycook, 2004; Piazza \& Hall, 2009; Swanson \& Kayler, 2008). However, the role of teachers' participation in critical literacy research, including a master's thesis, in developing a critical perspective on literacy education has received little attention.

\section{Participants and Context}

Two school instructors, Tatiana and Nijmeh, participated in the study. Table 1 shows some biographical information about the two participants:

Table 1. Biographical Information

\begin{tabular}{llll}
\hline & Tatiana & Nijmeh \\
\hline Date of birth & 1980 & & 1976 \\
Status & Married & Married \\
& 2013 & & 1997 \\
Children & 1 & & 5 \\
Teaching experience & Teaching ESL in elementary $\quad$ classes: & Teaching ESL in secondary \\
\hline
\end{tabular}


2005-2012

classes: 2000-present

Teaching ESL at universities: 2012-present

Degrees

BA in Teaching English to elementary ESL students

BA in English literature

2007

MA in TEFL

2015

Duration of thesis work $\quad 2013-2015$

2012-present

Both participants implemented critical literacy instruction for a whole year for their theses. However, Tatiana carried out this work with grade six students, while Nijmeh did it with grade 11 students. I have been supervising Nijmeh's thesis work (referred to as study 1), as part of my duties at a Lebanese University. Nijmeh also cooperated with me in a critical literacy study in 2014 (referred to as study 2). Moreover, I helped Tatiana in her thesis work, cooperating with a colleague who was supervising her at another Lebanese university. I taught Tatiana several courses during her undergraduate studies. I taught Nijmeh two graduate courses during her master's degree in TEFL. Tatiana, a Christian, mainly taught at schools affiliated with the Church. Nijmeh, a religiously committed Muslim, taught at a private educational institution affiliated with her Islamic sect and at a public school located in her religious community. For a detailed discussion of the significance of these affiliations, see Ibrahim (2015a).

Both Nijmeh and Tatiana had thought that critical literacy means teaching critical thinking when they developed their interest in working on it in their theses, but they differed in what motivated these interests. Tatiana attributed it to her learning experiences in two undergraduate language courses. However, Nijmeh, who maintained that she had not addressed critical thinking in her instruction before, chose to work on critical literacy in her thesis when I suggested the topic among several other alternatives. Thus, Nijmeh was motivated by fulfilling the master's requirement, and hence was unaware of the implications of working on what she thought was critical thinking, but Tatiana made a conscious choice based on a genuine interest and experience in critical thinking activities.

\section{The Study}

In this case study, data were collected from multiple sources, including:

Written reflections and oral interviews: Tatiana and Nijmeh wrote three to five reflections in response to specific questions and had four oral interviews with me. These tools sought knowledge about the participants' interest in critical literacy, about their teaching and learning experiences, about their successes in critical literacy instruction and about the challenges and conflicts as well as the consequential transformations they went through. Nijmeh did a few of these reflections and interviews during study 2 while Tatiana carried them out after she had finished writing her thesis. Also, the last interview sought the participants' reactions to the data analysis in the present study. The reflections and Published by SCHOLINK INC. 
interviews were interrelated in a way that each sought deeper insights and clarifications of ideas given in previous ones.

Informal conversations: During my work with the two participants, I had the chance to have informal conversations with them. These constituted an important part of the data; they shed light on the participants' religious, sociopolitical and socioeconomic backgrounds and on the way their positions affected their critical literacy work.

Some stories that the participants told were subjected to narrative analysis. Other data were organized under themes which emerged from the data itself. These themes, which were revised several times, constituted a springboard for thematic analysis.

\section{Results and Analysis}

Although Nijmeh and Tatiana conceptualized critical literacy as a new way of thinking, not only about instruction, but also about one's stance regarding many issues in life, they followed diverse paths towards their emerging personas. Nijmeh was religiously committed, conservative and reserved, but Tatiana was not a practicing religious person and possessed "a rebellious personality" as she said. As a result of the different ideologies, histories, and interests of Tatiana and Nijmeh, various challenges and conflicts emerged in their journeys, and diverse ways of handling them surfaced. These differences impacted the transformations they went through during their critical literacy experiences.

\subsection{Early Experiences and Challenges: Implications for a New Belief System}

Tatiana's undergraduate learning experiences, particularly in a language course and in a methodology course she took with me, inspired her to base her "teaching methods on making students think critically about (real-life issues) and about any text", even before she was introduced to critical literacy. She illustrated this influence with two pedagogical incidents. The first one referred to a discussion of the "Dead Poets Society" in a methodology course to illustrate the concept of intrinsic motivation in learning. "The teacher who came to change the old and useless methods at his school and who believed in his students and gave them space and voice inspired (Tatiana) to become like him".

The second was a discussion of civil marriage in a language course. I raised the topic because it was a point of debate in Lebanon, where marriage contracts are done in the church for Christians and in Islamic religious courts for Muslims. In 2004, the president of Lebanon proposed a law for civil marriage, which provoked a strong reaction from religious leaders, supported by a key political figure. Tatiana reflected the significance of this discussion to her in the following narrative:

I said that I am with civil marriage because I am with giving people the option to choose. All my classmates were shocked at my ideas. I felt they wanted to cut me into pieces. A married classmate said that she was against civil marriage because marriage in Christianity is a spiritual bond. I asked her: "if your husband cannot make sex, do you still marry him because marriage is a spiritual bond?" She did not answer.

Tatiana stressed that these incidents stimulated her desire to go "deeper and deeper into critical thinking 
and the world of questioning, evaluating and critiquing everything around (her)". These learning experiences seem to contribute to her vision of language education. Her attribution of her use of "The Dead Poets Society", the event of a collapsed building, and a religious text during her first three years of teaching to these experiences supports this point.

Tatiana used "The Dead Poets Society" with grade 6 students. She gave the following account of the lesson:

I did not prepare activities because I did not know how. Students watched it over three sessions in class because I assumed they will not understand it. I asked: “did you like it?" They said: "We liked Mr. Keating. Our school is similar to the school in the movie. We do the same as the scene of repeating and rhyming. The teachers and administrators who were against Mr. Keating are similar to the teachers at our school".

In another instance, Tatiana invested in the students' desire to talk about a building that had collapsed in their neighborhood in Beirut at that time. "When (she) entered class, the students were expressing pity towards the victims and blaming the owner for not obliging the residents to leave". Tatiana asked a number of questions which included: "Who is responsible? If your parents were in this situation, what would you expect them to do?" According to her, the students started seeing the problem from a different perspective and gradually shifting their views of which the criminal and the victim were. When they started attributing the delay of the residents to leave the building to their poverty, she brought to their attention the TV scenes which showed that they were not poor. She told them that the residents did not want to leave their houses before they got some compensation. The students concluded that "even if we will be on the street, (our parents) should save our lives".

In a third situation, the coordinator assigned a religious story about a poor man who used to live in the desert with his young child. The child used to complain about the lack of electricity, water shortage, the lack of computers, etc., but the father used to give the following justifications: "but we have stars, fountains, and animals". Tatiana made the students relate the lesson to socioeconomic conditions, as her account below indicates:

The text was a bit frustrating to me. I wanted the students to analyze the father's efforts to make his son accept (his circumstances). They first said that the story emphasizes the importance of living in nature. I asked: "If he wants to study, can he study in the light of the stars?" Some students said that maybe the father is lazy and does not want to work. I asked: "Why does the father want to send a religious message?" One student said: "The father wanted his child to shut up. Only God shuts us up. We use religion to make people shut up and accept reality and not to revolt". I was very happy with the answer. Tatiana's three narratives reveal how her undergraduate learning experiences informed her intuition to guide students in relating the utilized materials to real-life events and in questioning the discourses employed in these materials. Her strategies of questioning and comparing helped students examine how discourses manipulate the "truth". This is exemplified by how she engaged the students in questioning the discourses which blamed the owner of the collapsed building for the calamity and in contrasting 
them with details about how the residents appeared in the media. These practices seem to have enabled the students to analyze and challenge the myths engendered in the social, religious and political rhetoric, as Shor (2009) calls for. This is important, but questioning the myths engendered in any discourse does not mean a strong claim to the truth. For instance, the participant's belief that the residents of the collapsed building bear responsibility, unlike what the dominant discourses in the media show, and that religion is used in preachy distorting ways in the religious story dominated the questions she formed. Tatiana's subjectivity (feelings and beliefs) seem to have guided the discussion. Her questions made students focus on interpretations compatible with her beliefs and marginalize others. For instance, in the case of the religious story, alternative interpretations include the father's honest belief in what he is saying; the conflict of interests between the two family members; the father's submission to the religious discourse, himself being a victim of that discourse.

While one's subjectivity is where any critical instructor starts, one's feelings and reactions should be managed through an important dimension of a reflexive teacher, namely admitting one's position and opening the floor for all possible interpretations. While Tatiana could transfer important aspects of her undergraduate learning experiences into distinct instructional practices (analysis of discourses in terms of whether they promote a more just world), she appears to lack the ability to manage her subjectivity during the discussion of significant issues so that all possible interpretations are contemplated by students. While these instructional practices the participant had adopted before she started reading about critical literacy seem to have constituted critical moments in shaping her vision of language education, Tatiana appears to lack the reflexivity that connects these moments with theory, one dimension of which is to position herself as a facilitator of critical dialogues among students.

\subsection{The Difficulty with Theory}

When Nijmeh and Tatiana started reading for their theses, they discovered the differences between critical thinking and critical literacy, which confused them. They felt they needed solid theoretical grounds for critical literacy, which they found difficult to understand. They had to "read and re-read thoroughly", as Nijmeh stated. However, they reported different sources of and experiences in handling these difficulties. Tatiana did not find it easy to grasp the many terms used in the literature of "critical literacy (which address) many aspects of social justice ... like stereotyping, marginalization, sexism, etc.". At the beginning, this complicated the task of coming to grips with this approach, as Tatiana explained. However, Nijmeh was not that specific in explaining the source of her difficulty. While Freire's "complicated theoretical ideas" confused Nijmeh, a thorough reading of his works helped Tatiana "understand that critical literacy is reading the world through words and go beyond the lines". Tatiana's "love of Freire's ideas (motivated her to) deepen (her) knowledge of critical literacy". However, Nijmeh found Wallace's book (2003) more direct and reader-friendly than Freire's works, despite her appreciation of these works; it clarified her confusion. "(She) was interested in how Wallace treated the topic, how she treated the students, and how she did the activities. (She) understood how to apply it in the classroom". The different understandings the two instructors had of Freire's philosophy 
might be attributed to their views of teaching before they embarked on their theses. Tatiana believed that "the teacher is a leader" who should bring real-life issues to class and guide students to become change agents in their communities. However, Nijmeh did not seem to possess this view before she started working on her thesis. She conceptualized the role of the teacher as a technicist who applies conventional literacy instruction as he/she finds them in the textbooks. These varied views seem to partly explain the differing effects that Freire's ideas had on each of them.

In addition, Tatiana and Nijmeh varied in the degree to which they understood the different orientations to critical literacy. Nijmeh, for instance, explained that both Freire and Wallace have the same theoretical position. However, Tatiana could recognize that the positions of the two scholars are different. These variations may be attributed to the participants' different life conditions, which made Nijmeh invest a shorter time than Tatiana in reading about the topic. Nijmeh, who had five children, did not resume her work on her thesis after she had finished data collection. She explained that working in three schools was her priority in order to support her family. This, she added, left no time for her to engage "in the intellectual activity of reading, (which made her) feel guilty". According to her, "although (she) understood the main concepts of critical literacy, (she thought) that there might be different approaches and new research that (she) should read about". Tatiana, on the other hand, did not have kids during her graduate studies, which allowed her to finalize her thesis in two years.

These differences in the participants' investment in time also seem to have impacted the degree to which they benefited from my close guidance. Although I explained the different critical literacy orientations to both of them, Tatiana seemed to possess a clearer distinction between them. She explained:

"If you were not present, guided me in my thinking, told me about the different approaches, (and asked) me to adopt one of them, I would not have been able to do it. Maybe it needed a lot of time to know that there are three approaches". Hence, there should be not only encouragement, but close supervision of people interested in critical literacy. Also universities should give such courses.

The participants' thoughts reflect the struggles that they went through in seeking a clear theoretical background to orient their thesis work. While this is true of any topic, further complexity lies in that critical literacy is theorized as a human activity embedded in a particular sociopolitical and socioeconomic context, which makes it a theory with implications for practice (Behrman, 2006). Tatiana's statements "I did not feel (the theory) was in class" and "experiencing critical literacy with students is ... clearer than theories" illustrate the sophisticated task both participants faced in shaping their theoretical stances. What may have complicated this task to them is the tendency of many teacher-education programs to translate any pedagogical theory into an instructional formula easily transferable from one context to another (Morgan, 1997). Actually, many teachers are trained in applying pedagogical formulas prescriptively without any analysis of their theoretical grounds. This may explain the struggles that the two participants faced in doing their thesis work. However, while Tatiana could handle the struggles in a relatively short time, Nijmeh's obstacles in writing her thesis 
proposal worried me. Nijmeh's prolonged engagement with critical literacy seems to reverse this direction, and her idea that the practical part is much stronger than the theoretical part gives evidence to that effect. In the end, both emerged as very good critical literacy instructors, though with varied emphases.

\subsection{Praxis: Theory, Practice, Ideology, and Identity}

The data show that the praxis process through which the participants went involved more than just the connection between theory and practice. Their professional histories, their understandings of the critical literacy theory, and their ideological positions seem to interact and to impact how they reflected on their theoretical stances, on their instructional practices, on their beliefs, and on their evolving identities.

\subsubsection{Examining Earlier Experiences from a New Theoretical Position}

The data indicate that Tatiana's early experiences in critical thinking instruction made the connection between theory and practice smooth, while Nijmeh's sudden shift from conventional literacy practices to critical literacy instruction made the process harder. In her reflection on using the "Dead Poets Society" in her first year teaching, Tatiana explained: "I now know that the students' answers were based on critical literacy since the students evaluated the traditional school system, and they could critically find the flaws in their teachers' performance". This connection between her first-year-teaching experiences to the theory about which she read seven years later seems to have consolidated her concept of herself as a critical educator. Tatiana was "very proud about this experience but now (she) can say that it missed theoretical knowledge and many things". She added: "If I knew it was critical literacy, I would have changed many things". This reflection appears to facilitate the process of systematizing critical literacy instruction in Tatiana's implementation of her thesis. Tatiana also seems to continually connect theory with practice, which made her identify the difference between understanding the theory and adopting it in actual teaching. She said: "Okay, reading introduced me to critical literacy, but I experienced the real challenge in the discussion and the application. I did not expect that it is so challenging; it challenged their beliefs, my beliefs". Tatiana's idea that "even until now, (she) still misses many things in theory and its application" implies that through her reflexivity, she could determine the need to sharpen her theoretical stance as well as the instruction derived from it. It seems that the different experiences of Nijmeh and Tatiana, which led to varied reflexive processes, resulted in different attitudes towards critical literacy instruction. Tatiana approached her thesis work with enthusiasm and openness to new suggestions, and this helped her deal with the different difficulties she faced. However, Nijmeh exhibited some resistance, hesitance, and confusion during study 1. At that stage, she had doubts regarding the effectiveness of critical literacy instruction and about maintaining it in her classrooms, which seems to result from the sudden shift from traditional literacy instruction to a radically different teaching orientation and to the world view from which it is derived. In fact, Nijmeh modified some activities in study 1 and incorporated conventional literacy instruction because she could not do away with it. Probably, she felt more secure to hold to her old 
practices, particularly that her students had to sit for exams that were common with other sections, as she said. Her hesitancy appeared when she reported disappointment and frustration during the first quarter of study 2 because of the students' resistance to the unconventional tasks, as Nijmeh asserted. She even explained the persistent resistance of some students as follows: "Some students did not like the activities while others did. This may be attributed to them being low achievers or to their low language proficiency or it was just that they did not like them".

It appears that Nijmeh's explanation of the students' resistance to critical literacy instruction contributed to a delay in her identification with this orientation. In contrast, Tatiana's attribution of early student resistance to the manipulative educational system indicates a coherent understanding of critical literacy, as the following excerpt illustrates:

When I started doing these activities in class, I developed an absolute belief in how much our society suffers from social diseases and is built on disempowering people. The controlling school system brainwashes students to follow authorities. Many students submit to this system and become silenced and deep down unhappy with their life and wish to speak out like free students, but they can't because they lost the sense of security and self-esteem, and consequently did not interact well during the early stages of instruction. I knew that they needed more time and exposure to critical literacy to have voice inside active classrooms. After a while, they started to participate in the discussion, have a position and feel important. This will help them later on to have a stance in their real life.

\subsubsection{The Others' Discourses and Our Identities}

It seems Tatiana placed more emphasis on empowering students in her conceptualization of critical literacy, while Nijmeh had more stress on involving students more in learning. These diverse understandings of critical literacy and the ideologies that informed them appear to interact with the discourses of the participants in the educational process in shaping the two instructors' distinct professional identities. Nijmeh's investment in critical literacy was limited to her desire to finish her graduate work, which may explain her early resistance to this approach. It was not until she had recognized how students were much more responsive to critical literacy activities around real-life events than to conventional literacy activities that she started identifying with the term "critical". This took place late during the first half of study 2 . When the students started responding favorably to the tasks, she started feeling "happy with that because I felt this way I am having more involved students". While Tatiana reported how her students' discourse during her first teaching experience influenced her view of herself, Nijmeh started recognizing her new professional identity through the discourses of her students and her colleagues late in study 2. Tatiana "remembered very well, when she informed the students (with whom she used 'The Dead Poets Society' during her first teaching experience that she) won't be with them the coming year, how some of them stood on the desks and repeated 'Oh Captain, My Captain"'. This event symbolized to her that she instilled a rebellious attitude in her students and "made (her) proud because (she) knew that (she) achieved something with them". This feeling created by the students' discourse seems to represent a turning point in her dream to become like Mr. Keating. 
It stimulated her desire "to deepen her discovery in the critical field". This critical professional and emotional moment represented a shift in her newly developed identity because she "knew that (she) is a new type of teachers",

Unlike Tatiana who sought to help students rebel against unjust conditions, Nijmeh viewed critical literacy as a means to help students think deeply about texts. This supports the conclusion that the different learning and teaching experiences and the different world views of Nijmeh and Tatiana led to distinct understandings of critical literacy and to distinct professional identities. Nijmeh's conversation with one of her colleagues at school that took place on the day of the last interview with her illustrates these differences. It happened that this colleague also used to teach at a university, where many of Nijmeh's students who were involved in critical literacy for two years used to study. This colleague told her "that (her students) are smarter than other students". Nijmeh responded: "you know what? These students did many critical literacy activities. Maybe this is why they look smarter because they think and analyze".

Nijmeh's focus on deep thinking and analysis, in contrast to Tatiana's emphasis on student empowerment to reject injustices, reflects how each of them highlighted different dimensions of their new identities. These highlights seem to result from the different ways with which the two instructors evolved as critical educators and the different events in which they were involved. Despite these differences, the students' discourses, attitudes and reactions appear to have formed some common views. Both of them reported that their students noticed that they are different instructors and "there is something exciting about what we are doing because in other classes, all what teachers do is asking them to read aloud in turn and ask them about the tone and the theme", as Nijmeh maintained. Tatiana advanced a similar assessment to Nijmeh's:

The conventional teaching method is an underestimation of the students' thinking abilities. The students' interactions in critical literacy classes were genuine and from their real life experiences, unlike the fake interaction in other classes which didn't represent their life and interest at all. Even at times, I was amazed at what I could make students say, especially in my thesis.

These excerpts indicate that the recognition of the differences between conventional literacy and critical literacy classes had a significant role in the two instructor's growth of their new professional identities. Tatiana explained: "Preparing my thesis helped me in shaping my personality as a critical researcher, so I felt that I am becoming an important professional especially that I was one of among few interested in this area". This distinct personality was reinforced by the comments and attitudes of colleagues and professors, as the following selection indicates:

For some colleagues, I am a reference now (laughing) for research, for advice. One of my friends told me "that every time I hear critical thinking, you come immediately to my mind". After I had finished my thesis, my supervisor expressed her appreciation and belief in my potentials, which opened for me the doors to teach various university courses. Anyone who can do critical literacy, can do anything.

Pennycook (2004) described a practicum course, in which he found that seizing unplanned 
micro-critical moments to engage with teacher learners in dialogues about practical matters opened the door on a more critical perspective. According to him, the pursuit of those moments in a course that does not necessarily raise big critical issues might open possibilities for integrating thought, desire and action through reflexive thinking. In the present study, unplanned significant critical moments in the two participants' journeys arose during their involvement in a long planned course of action which brought up the participants' histories, beliefs and desires to the forefront. The interaction between the unplanned and the planned moments seems to be a bi-product of what constituted each participant's subjectivity. This interaction appears to lead to a cumulative effect in transforming the ideological positions and the instructional orientations and practices of the two instructors in significant ways.

\subsubsection{Ideology and Reflexive Thinking}

The two instructors went through different ideological conflicts that may partly be attributed to their discrepant ideological positions which they had held before they became involved in critical language instruction, and partly due to the groups of learners whom they taught. It appears that these conflicts gave rise to a reflexive process that brought about critical examination of their ideological positions as well as of their evolving theoretical understandings. Nijmeh's idea that she "has become a new person" and Tatiana's assertion that "critical literacy became a lifestyle" suggests that these conflicts led to the emergence of new personas in the two instructors.

While sharing ideas about possible materials for study 2 , Nijmeh demanded that we avoid one text that she used in study 1 titled "Professor's snub of creationists prompts U.S. inquiry". In brief, the text describes the case of a professor who refuses to give recommendation letters to biology students who do not believe in the theory of evolution. This has stimulated legal indictments against the professor by some students and student organizations at the university where he used to teach. Nijmeh narrated her story with the text as follows:

The topic was challenging. It should have been given to a higher level. I have explained it well, but they did not like it. I did not feel that it stimulated interaction. Students could not put themselves in the shoes of the professor to defend his position and mistake, which contradict their religious beliefs. They believe that he discriminated against students. Only one student said: since we are judging him as a discriminating person, we are being discriminatory ourselves.

Topics like evolution or abortion challenge students' values and beliefs and naturally lead to resistance (Shore, 1993; Reisboard, 2013). However, these same challenges constitute cornerstones for becoming what McLaren (as cited in Connolly, 2013) calls agentic, theorizing intellectuals who reflect on whether our beliefs and values are conducive to better life conditions. As Shor (2009) argues, controversial topics demand teachers who believe in the possibility of questioning anything; those teachers can help students see the value of and reduce their resistance to a questioning stance. Nijmeh claimed that she believed in this questioning approach and attributed the students' resistance to the idea that "they did not reach the stage at which they understand that we are just putting ourselves in the shoes of others, without necessarily changing our beliefs". She added that this is "maybe due to their 
religious background. Usually people are attached to their beliefs and find it difficult to surrender easily to the other party". She described this as stubbornness and inflexibility and suggested: "Students have to be exposed to situations like this, to other articles that show such people are misjudged and that they have the right to believe whatever they want". However, Nijmeh's resistance to include the "Professor's snub of creationists..." in study 2 indicates that she was still not able to make her students reflect on values so dear to many of them, to her, and to the local community which the school serves. In her reflection on this interpretation, Nijmeh stressed:

"Your analysis was right, really it was right. At one point, I felt that critical literacy contradicts my religious beliefs. A strong example was when I couldn't raise questions and facilitate the discussion to help students be in the professor's shoes because it challenged my belief system. I had this barrier. Because I had this conflict, I could not make the students raise questions and do further analysis. However, when I thought about it, I accepted it because we have to teach our students and even our children how to think and how not to accept everything they are told. We should be critical about everything, even about religion".

These ideas reveal that Nijmeh's ideological conflicts during her involvement in critical literacy led to a praxis process during which she reflected on her established belief system from her new position as a critical literacy instructor as well as on her understanding of critical literacy from her ideological position as a religious person. This reflexivity made her advance the following assessment of religion: "Sometimes, there are issues and practices that are not logical in religion. As believers, we were raised in such a way that we have to have faith because we are afraid not to believe in them, so we accept things as they are". It seems that this assessment made Nijmeh develop a new religious position in which she incorporated critical literacy derived from a distinct understanding of this approach. This understanding made her read a lot about her religion to find evidence "for some religious stories in order to relieve herself", as she stated. During this search, she "found contradiction between different points of view about some religious texts and stories. Some people say that they are not real but are just created and believed by some followers of the prophet". She then concluded that many religious ideas that we usually take for granted are constructed by people and "can, actually should be, questioned". This shows that Nijmeh has developed an important aspect of critical literacy, namely the view that texts and discourses, even religious ones, present interested versions of the reality. Consequently, she started "raising questions and going deep to prove whether they are right or not". This critical position seems to be a byproduct of the ideological challenges with which some critical literacy tasks presented Nijmeh and her reflections on her new way of thinking and teaching. It also seems to have led to significant modifications in Nijmeh's ideological position, as the excerpt below indicates:

Being stubborn in political and religious issues means that we lack awareness. Smart enough accepts criticism. Students have the right to interrogate the imposed social code and norms, with no compliance, and to accept what suits them in a way that respects others. We should accept the different points of view, be tolerant, and reach common grounds. There are marginalized people that we do not have to 
exclude.

This excerpt indicates rational thinking about matters that were not subject to rationalizing before. Her idea that her religious beliefs constituted barriers in the face of examining some inherent contradictions in these beliefs hints at the conflicts she experienced during the two studies. Her assertion that she overcame these barriers and that she developed a questioning approach illustrates how these conflicts brought about a reflexive process which helped her reason about her religious ideology. She sought support for that rationality in "(her) religion", the prisms of which allow her "to ask questions, except about sacred things".

A comparison between Nijmeh's ideological challenges and those Tatiana faced illuminates how different subjectivities lead to qualitatively different conflicts and different degrees of reflexivity. The following narrative of and interaction that took place in a university language course which Tatiana taught after she had finished her thesis illustrates this interpretation:

In a class discussion, the students, who included many veiled Muslims and some Christians, were all against abortion even when the child would be severely disabled. These were some of their arguments:

"Who are we to end one's life?"

"We should accept and tolerate calamities because they are from God".

I was shutting up. I couldn't tolerate. During the discussion, I said: "My niece suffers from mental retardation. She does not walk, hear or speak. Her Mother curses life one hundred times a day. Probably, the daughter will do the same in the future. Can we say we are against abortion? Can I tolerate my child's daily sufferings? Is it humanity to see people suffer? I do not want the God whom you are describing. I don’t want him".

I was upset a lot. I even cried because I remembered the terrible situation of my niece. I certainly now wish that nothing happens to her. But when she was still an embryo, one can tolerate losing her. One student insisted that humanity does not allow her to kill. I told her: "Where does humanity lie in what you are saying? Even God should ask people if they can tolerate a certain situation. I should have the choice. If religion is against forcing people to believe in certain ideas, why do you want to force us to do it?" Two people went out. Two students changed their opinion.

Obviously, Tatiana's sensitive personal experience with the issue was highly implicated in the debate. As the narrative indicates, Tatiana could not manage the effect of her emotions on her role in class discussion. Her anger, though understandable, reveals that her position and her blame of the individual students for being against abortion dragged her into an argumentative situation, which constituted limitations for analyzing the social discourses that shaped the students' beliefs. One challenge that a critical literacy instructor faces is to make students critically examine the discourses they use to express their opinions about a controversial issue, without letting her sincere emotions guide the discussion. In the end, empathy with the victims of injustice is an important goal of critical literacy, and one should be him or herself empathetic, i.e., emotional, in order to promote this sense of empathy among people. The extent to which one can manage his anger at injustice determines the degree of success in making 
people see it and recognize how texts and discourses can promote it. Teachers with a vision of a democratic and a just world can develop this ability through methodological rigor, which refers to the teachers' devotion to their profession in all its aspects: "scientific formation, ethical rectitude, respect for others, coherence, a capacity to live with and learn from what is different, and an ability to relate to others without letting our ill-humor or our antipathy get in the way of our balanced judgment of the facts" (Freire, 2001, p. 31). This seems a complex task, particularly the ability to tolerate an unjust discourse that impacts one's life significantly, so that all concerned parties can analyze it. Tatiana supports this complexity when she explained that critical conversations with students and others "are dangerous because they shock them, which might lead to rejection"; they are so also because they make her reflect on her values and thoughts. This, according to her, taught her not to be so shocking during such conversations. This indicates Tatiana's recognition of what may inhibit critical learning, in which the learners and the teachers are in a continuous process of transformation and during which both are the subjects of constructing and reconstructing knowledge (Freire, 2001). However, it seems she had difficulty in dealing with unjust discourses that affect her personally.

Another comparison between two instructional events illustrates the variable impact of the two participants' diverse teaching views on their reflexivity. In the last instructional sequence of study 2 , Nijmeh's students were asked to analyze a text about a new Lebanese controversial rent law. In Lebanon, rental contracts had been made on an old law before 1992, under the terms of which tenants used to have life-long contracts and owners could not raise rents. Apartments rented after this year are governed by a law legislated in 1992, under the terms of which contracts should be renewed every three years and the owner can raise the rents as much as he wishes. Nijmeh believed that this topic was not appealing to students because "most of them rent houses according to the new rent law and they weren't familiar with what the old rent law means". She noted that this made the topic not "of personal concern as they are students and it is a parent's worry to find decent and affordable housing. Two students only considered renting a house every person's concern". Nijmeh's observation is not congruent with the students' deep analysis of many aspects of unfairness caused by the presence of two laws. In addition, her comment that she could not make students interact about the new rent law because it does not affect them indicates that a few cramps of the approaches that isolate literacy from its context were still lurking in her new vision. In practice, Nijmeh took some measures to create desire in students to tackle the issue of rents with some background knowledge by asking them to read in Arabic about it. Conceptually, however, she still had questions about whether the topic should have been included. This reminds us of Huang's (2009) observation that injustices that affect large groups of people receive more attention than those affecting minorities who fall victim generation after generation. Subjecting such injustices to critical scrutiny represents a significant dimension of critical literacy, which Nijmeh did not seem to have possessed at that time. She did not appear to recognize that posing problems that affect minorities initiates students into new interests, sharpens their critical stances, and enriches their language. However, Tatiana's investment in events like the collapsed 
building, which affected a smaller group of people than the new rent law, indicates that she had this side in her repertoire.

It is worth noting that Nijmeh had conducted two critical literacy sequences about poverty with enthusiasm and success before the new rent law sequence. The poverty lessons, Mother Teresa and homelessness, were related to the themes in the official textbook, but the new rent law text was not. This may indicate Nijmeh's fear to tackle a topic which is unrelated to the curricular contents. However, one sequence about a suicide bomb attack that had happened close to the school during study 2 was conducted out of the curricular themes. Nijmeh reported that students interacted greatly during that lesson because they cared about the event (see Ibrahim, 2015b; Nijmeh had "Nadia" as a pseudo name). Thus, it may be that the students' unfamiliarity with the new rent law issue and the inclusion of this topic from outside the curricular content interacted and formed Nijmeh's concept of its relevance. On the other hand, Tatiana made use of the collapsed building event even before she read about critical literacy. It seems that the patterns of instruction and the views of teaching the two participants were adopting before they started their thesis work affected the duration each of them took to be able to challenge conventional literacy patterns and to become reflexive practitioners. Nijmeh needed a longer time than Tatiana to develop a coherent thinking in order to imagine alternative possibilities (Comber, 2001; McLaughlin \& DeVoogd, 2004; Pennycook, 2001) and to adapt one's practices to new circumstances (Behrman, 2006). However, Tatiana required a longer time than Nijmeh to engage in systematic reflection on one's beliefs and practices.

\subsection{At Last, Radical Views but a Balanced Approach}

Nijmeh maintained that her experiences in study 1 and study 2 helped her evaluate the dominant instructional patterns in language teaching critically. Accordingly, she started modifying these patterns or replacing them all together with critical literacy instruction, as conditions allow. She specified two main conditions that may constitute constraints in her use of critical literacy activities:

One refers to the needed preparation effort and time. This causes me not to use them all the time. However, the main reason is that I am teaching Grade 12 science students, who have to sit for an official exam, and who take three sessions of English per week. Had I been teaching grade 11 who do not have to sit for an official exam and who take six English sessions per week, I would have used more critical literacy activities.

This excerpt indicates a critical understanding of the limitations that official exams place on involving students in critical literacy, which (Moje, Young, Readence, \& Moore, 2000) observe. Nijmeh evaluated "official exam questions (as) a disaster" and gave the following examples:

- Define an anecdote.

- What type of introduction is this? What does it serve?

- What is the mood of the author?

- What is the pattern of organization?

- What is the thematic relationship between two paragraphs? 
According to her, "the skills required to answer (such) questions", which demand memorization, are limited and simple, and thus, "it is absurd to focus on the knowledge and skills mandated by official exam questions". She believed that the problem lies in that teaching to the exam constitutes the main purpose in language classes. This, according to her, makes textbooks focus on the knowledge and skills required by these exams, which, according to Bahruth (2004) and Comber and Nixon (2011) take the form of trivial, prepackaged questions with prepackaged correct answers. The participant challenged what Bahruth described as the stringent application of reading programs that do not actually engage students in deep reading comprehension. She emphasized: "When students repeat (the same) activities, they feel bored".

The data indicates that Nijmeh developed a high level of criticality of high-stakes assessment practices despite the emphasis placed on such practices nationally and internationally (Comber \& Nixon, 2011). She seems to have developed the courage and vision that Comber and Nixon call for in order to address these valid fears in this era of accountability and use standards as one of the sources of guidance and not as the sole performance indicator. Her thoughts below support this implication:

Actually, most official exam questions are not compatible with critical literacy. They need separate instruction. Certainly I do that myself because we have to prepare them for the official exam but I do other things also. This allows me to integrate it in a way not to harm students.

This implies that Nijmeh developed a repertoire of strategies to address the multiple dimensions of literacy ignored by such tests. The fact that "the Lebanese curriculum repeats the same themes in different classes using other texts" enabled her to use many activities she implemented in studies 1 and 2. Because "conventional activities are not related to real-life", she replaced them with critical literacy tasks around the same texts in the official textbook when possible, especially that these tasks "are interesting, challenging and creative, not just analytical and critical. Students come up with something they have thought of, not just bringing from the internet". She illustrated her point with two examples: A facebook activity (Ibrahim, 2015b) and critical questions and activities about obesity (see Table 2).

Table 2. The Facebook and the Obesity Lessons

\begin{tabular}{ll}
\hline Facebook & Obesity \\
\hline Students choose a Facebook image about an issue & Students wrote four questions about obesity. \\
of significance to them. & A class discussion, in which one group \\
They reflect on it through answering questions & represented the obese persons and another \\
like: & represented nutritionists. \\
"Why did you choose this particular image? What & The nutritionists asked the obese persons about \\
questions did it raise?" & many things related to their life-styles, to their \\
& interests and to their wishes and gave them some \\
& advice. \\
\hline
\end{tabular}


Some students' input during the group work:

"I don't like to be attractive".

"I like the way I am".

Nijmeh "liked the two activities a lot". According to her, the fact that "some students were obese stimulated their interest and made it significant to discuss the reasons for stereotyping and bullying obese people". Moreover, she considered the Facebook lesson as "moving away from the conventional instruction, which made students interact a lot. According to her, since "we are living in the age of technology, we should target digital literacy". These remarks show that Nijmeh could overcome significant challenges with which critical literacy presents teachers, namely, destabilizing usual classroom order and adapting to the uncertainty of open-endedness (Oberman, O'Shea, Hickey, \& Joyce, 2014). The data also indicate that she realized the "potential for critical inquiry in all that students and teachers do in schools" (Comber, 2001, p. 100). She seems to have worked within a modified curriculum that remains within the ministry guidelines and polices (McLaughlin \& DeVoogd, 2004).

\section{Conclusion}

This case study illustrates how the instructors' histories, their prolonged involvement in critical instruction, their different ideological positions, and their institutional and communal context interacted in complex ways and led to significant transformations in their views of the world and of literacy instruction - transformations that McLaughlin and DeVoogd (2004) deem necessary in adopting critical instructional orientations. The study suggests that participating in critical literacy research under the guidance of an expert in the field may present one significant approach in facilitating such transformations. It also implies, among other things, that teachers who would like to adopt such a view of literacy education should be involved in a prolonged engagement with theory and practice so that they are empowered with the reflexivity needed to handle the various challenges and conflicts that result from putting critical literacy into practice. Thesis work involves cooperation with individual teachers and students in this prolonged involvement. It would be interesting to explore such prolonged involvement in reflexive practices in teacher-training programs that address groups of students in regular classes as well as the challenges that such programs face.

\section{References}

Bahruth, R. (2004). Critical literacy vs. reading programs: Schooling as a form of control. International Journal of Learning, 11, 509-515. Retrieved January 7, 2015, from http://www.ijl.cgpublisher.com

Bartolomé, L. (2004). Critical pedagogy and teacher education: Radicalizing prospective teachers. Teacher Education Quarterly, 31(1), 97-122.

Behrman, E. H. (2006). Teaching about language, power, and text: A review of classroom practices that 
support critical literacy. Journal of Adolescent \& Adult Literacy, 49, 490-498.

Benesch, S. (1993). ESL, ideology, and the politics of pragmatism. TESOL Quarterly, 27(4), 705-717.

Bercaw, L. A., \& Stooksberry, L. M. (2004). Teacher education, critical pedagogy, and standards: An exploration of theory and practice. Retrieved from http://www.usca.edu/essays/ vol122004/Bercaw.pdf

Cho, H. (2015). "I Love this Approach, But Find It Difficult to Jump in with Two Feet!" Teachers' Perceived Challenges of Employing Critical Literacy. English Language Teaching, 8(6), 69-79.

Comber, B. (2001). Critical literacies and local action: Teacher knowledge and a "new" research agenda. In B. Comber, \& A. Simpson (Eds.), Negotiating critical literacies in classrooms (pp. 271-282). Mahwah, NJ: Erlbaum.

Comber, B., \& Nixon, H. (2011). Critical reading comprehension in an era of accountability. The Australian Association for Research in Education, 38, 167-179. http://dx.doi.org/10.1007/s13384-011-0022-z

Connolly, B. (2013). Theorizing creative, critical pedagogy: The art of politicized agency. Retrieved from http://www.rizoma-freireano.org/index.php/theorising-creative-critical-pedagogy

Crookes, G. (2010). The practicality and relevance of second language critical pedagogy. Language Teaching, 43(3), 333-348.

Crookes, G., \& Lehner, A. (1998). Aspects of process in an ESL critical teacher education course. TESOL Quarterly, 32(2), 319-328.

Freire, P. (1993). Pedagogy of the city. New York, NY: Continuum.

Freire, P. (2001). Pedagogy of Freedom. New York: Rowman \& Littlefield.

Freire, P., \& Macedo, D. (1987). Literacy: Reading the word and the world. South Hadley, MA: Bergin \& Garvey.

Giroux, J. (2007). Educated hope in dark times: Critical pedagogy for social justice. Our Schools, Our Selves, 17(1), 195-202.

Gregory, A., \& Cahill, M. (2009). Constructing critical literacy: Self-reflexive ways for curriculum and pedagogy. Critical Literacy: Theories and Practices, 3(2), 6-16. Retrieved October 28, 2012, from http://www.scholarworks.boisestate.edu/literacy_facpubs/62/

Hall, G. (2005). Thinking locally: Addressing the dilemmas raised by Critical Pedagogy in ELT. Retrieved from http://www.developingteachers.com/articles_tchtraining/criticalpedagogy_ graham.htm

Huang, S. (2009). EFL reading through a critical literacy perspective. English Teaching \& Learning, 33(3), 51-93.

Ibrahim, N. (2015a). Critical literacy: Performance and reactions. Theory and Practices in Language Studies, 4(4), 756-764.

Ibrahim, N. (2015b). Politics and identity in an EFL class: Did you say a suicide bomb attack? Studies in English Language Teaching, 3(4), 439-465. 
Kanpol, B. (1998). Critical pedagogy for beginning teachers: The movement from despair to hope. Retrieved from http://www.lib.umwestern.edu/pub/jcp/issueII-1/kanpol.html

McLaughlin, M., \& DeVoogd, G. (2004). Critical literacy as comprehension: Expanding reader response. Journal of Adolescent \& Adult Literacy, 48(1), 52-62. http://dx.doi.org/10.1598/ JAAL.48.1.5

Moje, E., Young, J., Readence, J., \& Moore, D. (2000). Reinventing adolescent literacy for new times: Perennial and millennial issues. Journal of Adolescent \& Adult Literacy, 43(5), 400-410.

Morgan, W. (1997). Critical literacy in the classroom: The art of the possible. NY, NY: Routledge.

Morrell, E. (2005). Towards a critical English education: Reflections on and projections for discipline. English Education, 37(4), 312-322.

Norton, B., \& Toohey K. (Eds.). (2004). Critical pedagogies and language learning. New York: Cambridge University Press.

Oberman, R., O’Shea, F., Hickey, B., \& Joyce, C. (2014). Children's Global Thinking: Research Investigating the Engagement of Seven- to Nine-Year-Old Children With Critical Literacy and Global Citizenship Education. Dublin, Ireland: St Patrick’s College.

Pavlenko, A. (2003). "I never knew I was a bilingual": Re-imagining teacher identities in TESOL. Journal of Language, Identity, and Education, 2(4), 251-268.

Pennycook, A. (1999). Introduction: Critical approaches to TESOL. TESOL Quarterly, 33(3), 329-348.

Pennycook, A. (2001). Critical applied linguistics. Mahwah, New Jersey: Lawrence Erlbaum.

Pennycook, A. (2004). Critical moments in a TESOL praxicum. In B. Norton, \& K. Toohey (Eds.), Critical pedagogies and language learning (pp. 327-345). New York: Cambridge University Press.

Piazza, S. V., \& Hall, L. A. (2009). Sociocultural and Political Literacies in Teacher Education. Paper presented at the Annual National Reading Conference, Albuquerque, NM.

Reisboard, D. (2013). Going beyond the efferent: Teachers' critical literacy development using picture books. Journal of Modern Education Review, 3(6), 468-477.

Shor, I. (1993). Education as politics: Paulo Friere's critical pedagogy. In P. Leonard, \& P. Mclaren (Eds.), Paulo Freire: A critical encounter (pp. 25-35). New York: Routledge.

Shor, I. (2009). What is critical literacy. In A. Darder, R. D. Baltodano, \& M. Torres (Eds.), The critical pedagogy reader (pp. 282-304). New York: Routledge.

Swanson, K. W., \& Kayler, M. (2008). Co-Constructing a Learner-Centered Curriculum in Teacher Professional Development. Journal for the Practical Application of Constructivist Theory in Education, 3(1), 1-26. 